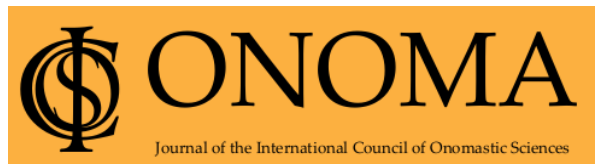

Onoma 56

Journal of the International Council of Onomastic Sciences

ISSN: 0078-463X; e-ISSN: 1783-1644

Journal homepage: https://onomajournal.org/

\title{
Naming holy wells: A case study of names on sacred springs in Denmark
}

\section{Johnny Grandjean Gogsig Jakobsen*}

Department of Nordic Studies and Linguistics

University of Copenhagen, Denmark

To cite this article: Jakobsen, Johnny Grandjean Gøgsig. 2021. Naming holy wells: A case study of names on sacred springs in Denmark. Onoma 56, 235-250. DOI: 10.34158/ONOMA.56/2021/12

To link to this article: https://doi.org/10.34158/ONOMA.56/2021/12

(C) Onoma and the author.

\section{Article history}

Received on 10 December 2020.

Final form accepted on 11 December 2021.

Published online on 13 December 2021.

Naming holy wells: A case study of names on sacred springs in Denmark

Abstract: The majority of the 720 historically-known springs in Denmark have been accredited with healing power of supernatural origin, manifested in their names and/or local folklore tradition still supported by cultic rituals celebrated way into the nineteenth century. While only 2.5 per cent of Danish spring names explicitly appear to be of pagan origin, at least 32 per cent were dedicated to Christian saints or named from other ecclesiastical terms, whereas 25 per cent had the religiously neutral name Helligkilde. Based on a case study of spring names in the region of north-western Sjælland, the whole question of age is discussed, just as several cases show how spring names and their attached folklore etymology are not always to be taken at face value.

Keywords: Place names, holy wells, folklore, Denmark. 
Nommer les bonnes fontaines : Une étude de cas sur les noms de sources sacrées au Danemark

Résumé : La majorité des 720 fontaines historiquement connues au Danemark ont été accréditées avec un pouvoir de guérison d'origine surnaturelle, se manifestant par leurs noms et/ou la tradition folklorique locale encore soutenue par des rituels cultuels célébrés jusqu'au XIX ${ }^{\mathrm{e}}$ siècle. Alors que seulement 2,5\% des noms de fontaines danois semblent explicitement d'origine païenne, au moins 32\% étaient consacrés à des saints chrétiens ou nommés à partir d'autres termes ecclésiastiques, tandis que $25 \%$ portaient le nom religieusement neutre Helligkilde. Sur la base d'une étude de cas des noms de fontaines dans la région du nord-ouest du Sjælland, toute la question de l'âge est discutée, tout comme plusieurs cas montrent comment les noms de fontaines et leur étymologie folklorique ne doivent pas toujours être pris au pied de la lettre.

Mots-clés : Noms de lieux, fontaines à dévotion, folklore, Danemark.

\section{Heilige Brunnen benennen: Eine Fallstudie von Namen der heiligen Quellen in Dänemark}

Zusammenfassung: Die Mehrheit der 720 historisch bekannten Quellen in Dänemark wurde mit Heilkraft übernatürlichen Ursprungs akkreditiert, die sich in ihren Namen und/oder ihrer lokalen Folkloretradition manifestiert, die noch bis weit in das 19. Jahrhundert hinein durch kultische Rituale gestützt wird. Während nur 2,5 Prozent der dänischen Quellen-namen ausdrücklich heidnischen Ursprungs zu sein scheinen, waren mindestens 32 Prozent christlichen Heiligen gewidmet oder nach anderen kirchlichen Begriffen benannt, während 25 Prozent den religiös neutralen Namen Helligkilde hatten. Basierend auf einer Fallstudie von Quellen-namen in der Region im Nordwesten von Sjælland wird die gesamte Frage des Alters diskutiert, ebenso wie mehrere Fälle zeigen, daß Quellen-namen und ihre damit verbundene Folkloreetymologie nicht immer zum Nennwert zu nehmen sind.

Schlüsselbegriffe: Ortsnamen, heilige Brunnen, Folklore, Dänemark. 


\title{
Naming holy wells: A case study of names on sacred springs in Denmark
}

\author{
JOHNNY GRANDJEAN GøGSIG JAKOBSEN
}

\section{Introduction}

The Danish landscape is dominated by water. In spite of covering an area of a mere 43,094 square kilometres, Denmark has a coastline of 8,750 kilometres, and no location is situated more than 52 kilometres from the sea. Even within the coastline, 1.6 per cent of the inland area is covered by open water in the form of lakes, bogs, rivers and smaller streams. Much of the inland freshwater deposits derive from rainfall, but a significant amount of it flows to the surface from beneath in the form of springs. From groundwater aquifers, subsoil streams of freshwater reach the surface all over Denmark in all kinds of landscapes. Danish freshwater springs are characterized by having a constant temperature of $3-10^{\circ} \mathrm{C}$ (thus, they never freeze), they contain several minerals, they often occur in hilly terrain on top of hard calcareous material (as sandstone or limestone) or from sand deposits laying on top of clay - and they can emerge and stop due to subsoil changes. Due to their quality as a steady supply of drinking water, springs have naturally attracted human settlements at all times. Perhaps because of their healthy mineral qualities, their capability of flowing through the hardest of winters and droughts, and their ability to suddenly occur without no apparent reason, numerous springs have since ancient times been accredited with supernatural, religious and healing powers (Arwidsson 1965: 53-54). While springs seem to have been intensively included in Celtic and Roman cults, their role in early-medieval German religion appears less profound, but some evidence for the cult of springs in pre-Christian Scandinavia is suggested by the sources (Arwidsson 1965: 54-55; Bø 1965: 57). Although it is traditionally claimed or indicated in Scandinavian literature that the Church at its arrival around AD 1000 basically Christianised an already-existing pagan spring cult (e.g. Bø 1965: 57; Svane 1984: 13-18), it has also been suggested that the cult to a large degree was in fact introduced with Christianity, as the Catholic Church by the time of its arrival to Scandinavia had fully accepted and included the spring cult encountered in the Celtic regions (Arwidsson 1965: 55). Certainly, the late medieval rituals connected to the Danish spring cult, as well as the attribution of healing power to the water, appear to be of a predominantly Christian origin (Arwidsson 1965: 55). 
When Lutheran Evangelism replaced Roman Catholicism in Denmark at the Reformation in 1536, it at first seems to have had little impact on the religious use of holy wells. But as Danish Protestantism was challenged by a possible Catholic counter-reformation in the first half of the seventeenth century, the royal and ecclesiastical administration took a hard turn against anything having even a remote scent of "Papism" - including the cult of sacred springs and the saints often associated with them. Apparently, though, the folkloristic popularity of holy wells was too strong for the Danish Crown and Church to suppress, as numerous tales describe how in particular King Christian IV (1588-1648) had wooden crosses torn down at spring sites all over the kingdom, only to see them resurrected the next morning by supernatural or divine intervention. Indeed, although actual Catholicism had absolutely no influence in Protestant Denmark until the late nineteenth century, holy wells with connected rituals and festive celebrations - including spring fairs with markets - were wellestablished and popular institutions until that very same time.

One should, of course, be careful to project the well-described spring cult rituals from eighteenth- and nineteenth-century Denmark to medieval times, but what can be read from written records from the Middle Ages along with archaeological evidence suggest that at least some of the rituals practised go back far. After having drunk from the spring water or having bathed one's sick body parts in it, the cup used to contain the water was often broken and dropped into the well, along with coins and other metal objects as an offering. It was also possible to increase the effect by donating monetary alms to a local parish church or monastery, sometimes in a chapel or collection box put up at the site. Likewise, many holy wells appear to have been marked with a big wooden cross in the Middle Ages. The healing power of the sacred water was often believed to be at its highest at certain times of the year, such as the Eve of St John (23 June). It was apparently sought for all kinds of illnesses, but especially rheumatism, skin and eye diseases, and rickets seem to have led many to the wells - not least women and children (Schmidt 1926: 52-74; Møller-Christensen 1939; Arwidsson 1965: 56; Svane 1984: 23-32). If anything, it could appear as if the Christian-sacred element of the cult in an ecclesiastical sense gradually diminished after the Middle Ages, to become more supernatural in its form with a less distinct Christian aspect, just as the role of markets and popular festivity at the spring site seems to have grown in post-Reformation times. 


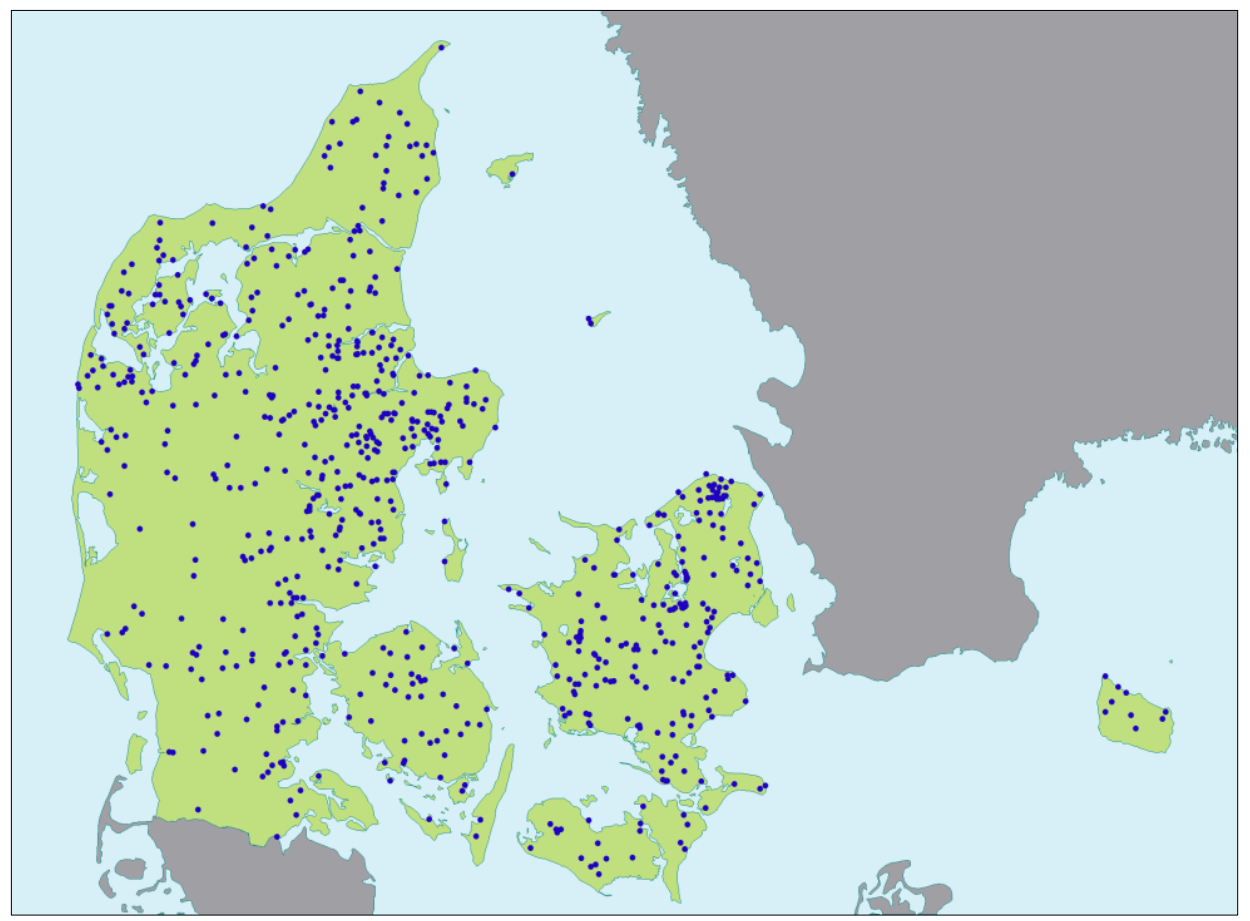

Figure 1: Distribution of the 720 Danish springs recorded by Siegfred Svane. Map by author after Svane (1984: 7 and passim).

In 1926, August F. Schmidt published a catalogue of all holy wells in Denmark as recorded by the Danish Folklore Society (Schmidt 1926). While he could find about 600 cases altogether, a new major and interdisciplinary survey led by Siegfred Svane in 1976-1983 found a total of 720 springs, both including those still existing and those recorded in nineteenth or earlytwentieth century sources, but no longer existing by the time of the survey. On average, about a third of the historically known springs had disappeared, usually due to farmland drainage; another third still flew to produce wet soil or ponds, but otherwise unmarked in present-day landscape; while only the remaining third was both running and marked with still-existing stone-built constructions. Along with the names and location of the springs, Svane also listed attributed tales and traditions linked to them, which he had come across in the records and from local visits (Svane 1984: 9-12).

The holy wells of Denmark have until now mainly attracted the interest of folkloristic scholarship, which apart from Schmidt and Svane has taken a predominantly local focus. Although the onomastic scholarship of Denmark on several occasions has taken up both sacred place names (e.g. Fellows-Jensen \& Holmberg 1992) and hydronyms (e.g. Sørensen 1968-1996), no Danish studies so far have been devoted especially to the naming of holy wells. In the following, I will try do so in a preliminary approach with a regional case study from the north-western part of Sjælland (Holbæk county) with comparative 
views to the rest of Denmark. While Svane had recorded 30 springs within this test region (and another eight springs are included on the most recent maps from the Danish Geodata Agency), I have only included 24 of the instances in my survey, as these are the only ones that according to their names and/or preserved folklore traditions have been accredited with any religious element. ${ }^{1}$ Thus, the case study-area represents 4 per cent of the entire Danish material as recorded by Svane.

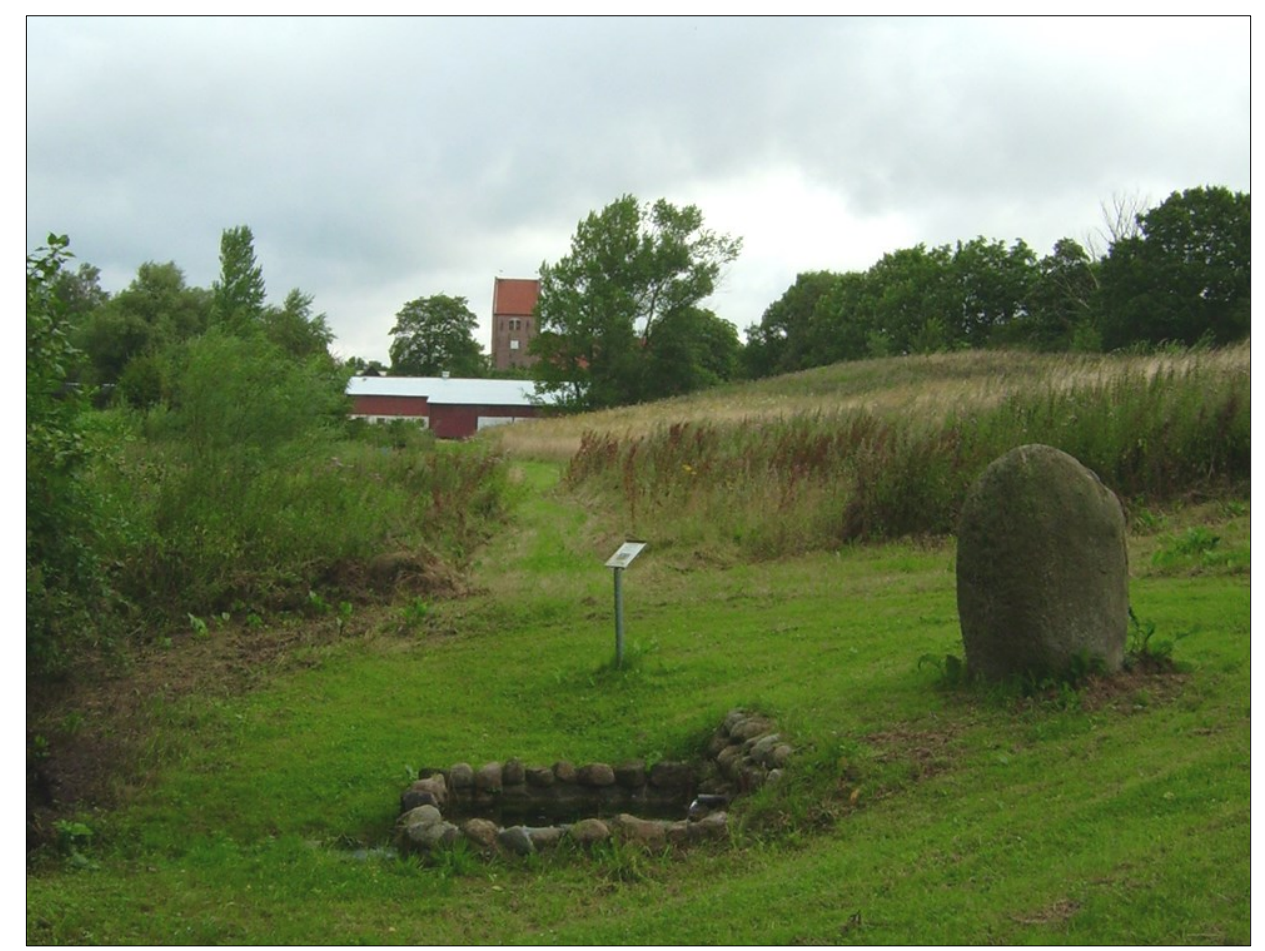

Figure 2: Only a minority of the holy wells of medieval Denmark are still as well-preserved and clearly marked in present-day landscape as the one of St Severin (Skt. Sørens Kilde) near Holmstrup in north-western Sjælland. The well became a significant regional centre of pilgrimage in the fifteenth century. Holmstrup Church is seen in the back. Photograph by the author.

1 Besides the 24 instances included by me, Svane also listed the springs Lettekilde (Hagested parish), Hundekilde (Hagested p.), Lundekilde (Ruds Vedby p.), Helene Kilde (Ruds Vedby p.), Ester Kilde (Ruds Vedby p.), and Kongskilde (Årby p.). The Danish Geodata Agency also has Snogekilde (Hagested p., perhaps identical to the abovementioned Hundekilde), Edvardskilde (Frydendal p.), an unnamed spring at Torbenfeld (Frydendal p.), Majorens Kilde (Buerup p.), an unnamed spring at Kattrup (Buerup p.), an unnamed spring west of Tissø (Svallerup p.), Vindekilde (Røsnæs p.), and one unnamed spring near Holmstrup (Holmstrup p.). The abbreviations p. and c. are hereafter used for 'parish' and 'county' respectively. 


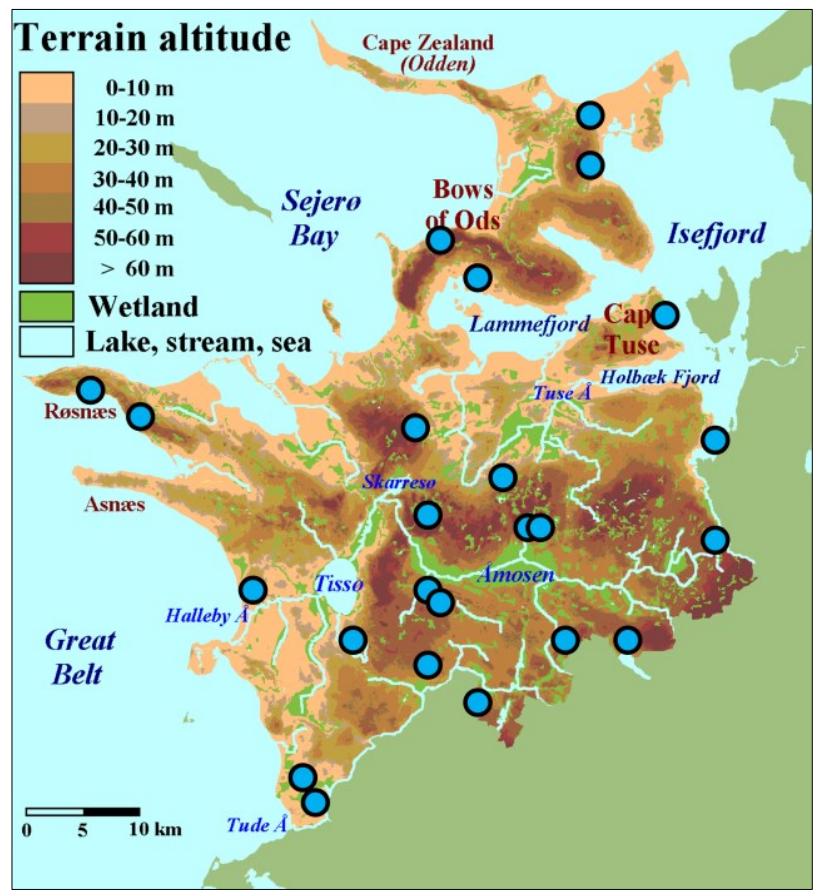

Figure 3: Distribution of the 24 holy wells in north-western Sjælland included in my case study, mapped on a background showing the physical terrain of the region.

\section{Names for holy wells in Denmark}

In Old Danish (OD), two different words were used to term a spring: kcelda (today kilde) and brun (today brønd), more or less equivalent to the English words spring and well respectively. In modern Danish, brønd differs from kilde by nominating a man-made construction to ease access to a (natural) spring or to subsoil groundwater. Both words feature quite commonly in Danish place names. According to the online database Danske Stednavne, 1618 place names contain the word kilde, in 649 instances as the generic, while 240 names contain brønd, 44 of them as generic. One particular place name occurs in both statistics, namely the settlement- and parish name Kildebrønde (Roskilde county), which at first sight could appear to have the pleonastic meaning 'spring-well', but a closer look will establish an original form OD Geldebrun, pointing to the meaning 'dry well' or 'well in a barren area' (Jørgensen 2008: 154); the example serves to stress that not all Danish place names in kilde and brønd should be interpreted at face value. ${ }^{2}$ Still, with 649 recorded generics in -kilde versus only 44 in -brønd, the statistics nevertheless

2 Also it needs to be noted that often groups of the names recorded in the database derive from just one single spring, which have produced secondary place names on settlements, fields, meadows, streams, etcetera named from the spring. 
firmly establish that the predominant generic for Danish spring names (and secondary settlement names derived from them) is -kilde. Likewise, in the case study-region of north-western Sjælland, 22 of the 24 included holy wells have names with the generic -kilde (alternatively the definite form -kilden or the pluralis form -kilderne); the only exceptions are Ravnehullet ('Raven's Hole') and the (here truly) pleonastic name Nykilde Brønd ('Newspring Well').

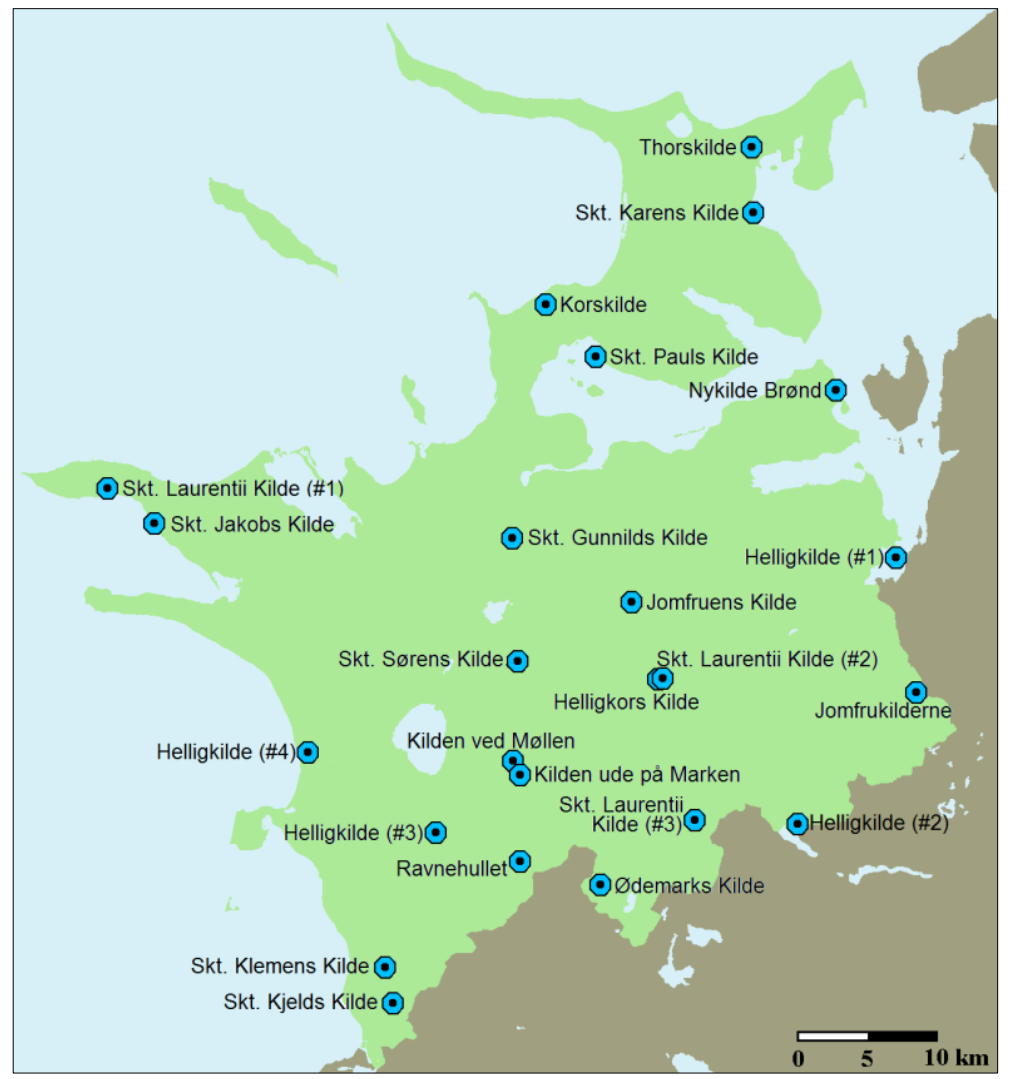

Figure 4: Distribution and names of the 24 holy wells in north-western Sjælland

The most commonly found name for holy wells in north-western Sjælland is Helligkilde ('Holywell' or 'Holyspring'), which simply derives from the basic Danish term of the named feature. While four or 17 per cent of the 24 sacred springs in the region are named Helligkilde, the name accounts for an astonishing amount of 183 out of the 720 springs recorded in total by Svane - i.e. 25 per cent of the entire Danish material! That a well by its name is claimed to be holy does not by itself suggest anything about whether this holiness derives from pagan or Christian times. For Helligkilde \#1 (at Munkholm, Ågerup p.), an attached tale has it that the spring emerged where a monk had been killed by local peasants, and later on the water was used by "wise women", who also collected healing herbs in the adjacent Munkehave 
('Monk's Garden') (Svane 1984: 82). The folkloristic explanation may just derive from the overall name of the locality, Munkholm ('Monk's Islet'), for which itself the origin is obscure, as the site is not known to have ever housed a monastery. For Helligkilde \#2 (at Søtofte, Tåstrup p.), no tales of its origin or use are extant, but it is situated by a burial mound called Kildehøj ('Spring Hill') and a Neolithic long barrow with Bronze Age cupmarks, which also points to a considerable age for the spring (Svane 1984: 84). For the region's remaining two instances of Helligkilde (\# 3 at Kildebrønd, Finderup p.; and \#4 at Bjerge, Svallerup p.) there are no indications of their age, but cultic rituals were still celebrated by the mid-nineteenth century (Svane 1984: 86-87).

\subsection{Pagan spring names}

Actual pagan elements are indicated in only two of the region's spring names. Thorskilde (Nykøbing p.) would at first point to the Nordic god Thor, who appears to have enjoyed widespread popularity especially among common folks in late Viking Age Denmark - also in terms of place-naming. For the whole of Denmark, Svane found an additional five instances of springs apparently named after this particular god, whereas the gods Odin, Balder, Frej and Tyr were connected by their names to one spring each. However, at least in the case of Thorskilde at Nykøbing, it should be noted that the spring (for which no tales or cultic traditions are recorded) is situated close to a longdeserted village, Torup, and although the oldest recorded form for this is indeed Thorthorp (1370-80), the extensive number of Danish settlements named Torup, Tårup, Tåstrup and alike, are traditionally not ascribed directly to the pagan god name, but rather to personal names derived from this, such as OD Toke, Tore and Torsten (Jørgensen 2008: 302, 312; Gammeltoft 2009). The local field name Torsjordene ('Thor's Lands') is quite certainly named from the deserted village, and it is therefore possible that also the names of the spring Thorskilde and a nearby hill Torsbjerg ('Thor's Hill') may just derive from the adjacent settlement name Torup, and if so have no direct name relations to the Nordic god of thunder.

All this notwithstanding, I would by no means suggest a similar rejection of the remaining Danish spring names with apparent relations to pagan gods. On a national level, Svane could also record four instances of the name Viekilde, where the specific can hardly be interpreted as anything but the OD *wī, 'pagan sanctuary', and thus strongly suggests a pre-Christian cult connected to the spring. While no wells of this name are recorded in northwestern Sjælland, the case-study region contains another instance which may be of pagan interest: Ravnehullet ('Raven's Hole', Ørslev p.). Although the specific of the name, the bird name ravn ('raven'), at first hand is religiously neutral, ravens are in Danish folklore traditionally closely linked to Odin, the king of the Nordic gods, who had two ravens (named Hugin and Munin) that 
informed him on a daily basis on all events going on in the world. Likewise, sacrifices to Odin were made by hanging up animals and humans in trees, where ravens performed the intermediary transfer of the sacrifice to their master. Thus, the raven carries a strong symbolic pagan-religious meaning in Danish folklore, and therefore it is noteworthy that ravens more than any other animal are found as specific in Danish spring names. Apart from Ravnehullet, Svane also listed Ravnekilderne (Esbønderup p., Frederiksborg c.), Ravnkilde (Ravnkilde p., Aalborg c.) and Ravnskilde (Gudum p., Ringkøbing c.). In the case of the former, there is no explanatory tale for the origin of the name, but a traditional spring cult was attached to the well (Svane 1984: 86-87). Still, even when including the ones with ravn in the specific, only 2.5 per cent of the spring names in Denmark have specifics pointing to a pagan-sacred origin.

\subsection{Christian spring names}

A significantly larger share of Danish spring names has Christian-sacred specifics. None of them were named directly after Christ himself, but Kristi Blods Kilde ('Well of the Blood of Christ') was dedicated to his sacrifice for mankind, as well as to a miraculously bleeding crucifix in Bistrup at Roskilde (Roskilde c.) (Svane 1984: 76). ${ }^{3} 14$ Danish wells were dedicated to the Holy Cross, either as Korskilde or Helligkorskilde. Two of these were located in north-western Sjælland, where the cult was maintained until the nineteenth century, including collection boxes put up by the local parish priests. The one in Undløse parish was allegedly found by a noble maiden, who in a dream was told to bathe her eyes with its water, which miraculously cured her fading eyesight (Svane 1984: 84, 89).

\subsubsection{Springs named after saints}

216 (or 30 per cent) of the Danish springs were dedicated to Christian saints. Most venerated in this respect was the Holy Virgin (21), John the Baptist (19), St Lawrence (14), St Olav (14), St Nicholas (10), and St Anne (8). While the abovementioned saints were all also highly popular as patrons for medieval parish churches in Denmark, a particular veneration as "spring saint" can be claimed for St Helen with 13 springs named after her, but only with very few church dedications. ${ }^{5}$ A special regional veneration is noted for the cult of St Thøger (Theodgar), a German missionary buried in Vestervig (Thisted c.), who apparently was responsible for 10 wells emerging around northern Jylland.

3 Likewise, one spring was dedicated to Corpus Christi (Helliglegemskilde, Vorbasse p., Ribe c.), and two to the Holy Trinity (Hellig Trefoldigheds Kilde, Kappel p., Maribo c.; Trefoldighedskilde, Seest p., Ribe c.).

$4 \quad$ St Olav and St Brigitte were particularly widespread as saints of springs in Norway and Sweden respectively (Arwidsson 1965: 55-56; Bø 1965: 58).

5 A Helene Kilde is in fact also located in north-western Sjælland (Ruds Vedby p.), but with no known tradition of any healing power, cultic celebration or tales regarding the background for its name (Svane 1984: 86). 
From the abovementioned elite ranks of spring saints, only St Lawrence was represented with wells in north-western Sjælland - but then with no less than three. In all three cases, his spring cult was closely associated with the local parish churches, even though the well itself was only physically situated by the church in Ulstrup (\#1, Røsnæs p.). ${ }^{6}$ St Lawrence was patron saint of both the parish churches of Røsnæs and Undløse, and a side altar was dedicated to him in Stenlille. Especially the church in Undløse was considered an important regional centre of pilgrimage for the veneration of St Lawrence, with extensive mural paintings dedicated to his martyrdom. For the well in Ulstrup, the healing power of the water was said to be particularly strong, if the person seeking it also walked three times around the church at midnight; in post-medieval times, there was even a servant affiliated to the church especially for the task of assisting sick people in making this nocturnal walk (Svane 1984: 84, 87).

Contrary to what might be expected, the wells of St Lawrence were not to be visited at the Feast of St Lawrence (10 August), if the visitors wanted the maximum effect of the holy water, but rather at the Eve of St John the Baptist (23 June). This was not a particular issue for St Lawrence, as spring cult celebrations in general rarely took place on the feast days of the connected saints. Except in the case of springs dedicated to the Holy Virgin, where the celebrations usually did indeed take place on one of the several feasts of $\mathrm{St}$ Mary, most regions had one particular day on which spring cults were enacted regardless of the saints involved. In most of Denmark, holy wells were thought to hold particular strong power on the Eve of John the Baptist, in Jylland also on Walpurgis Night (30 April) (Arwidsson 1965: 55; Svane 1984: 23). ${ }^{7}$

In spite of her general popularity as a saint of springs, the Virgin Mary apparently had no springs dedicated to her in north-western Sjælland. The region does include a Jomfruens Kilde ('Virgin's Well', Mørkøv p.), but this was according to local tradition not associated with the Mother of Christ, but rather a local, unfortunate maiden, who was murdered on her way to church, after which a holy well emerged at the scene of the crime (Svane 1984: 86). Likewise, Jomfrukilderne ('Virgin Wells', Soderup p.) allegedly sprang where three local girls were killed by three highwaymen, who by dark misfortune also happened to be their biological brothers (Svane 1984: 82-83). However, one should probably not dismiss the possibility that at least some of the 'virgin wells' around north-western Sjælland originally may have been associated with the Holy Virgin, and only later, in post-Catholic folklore tradition, were replaced by unfortunate local maidens.

$6 \quad$ Skt. Laurentii Kilde \#2 (Undløse p.) was located at Lejsbjerg on the road between Ulkestrup and the church village of Undløse, while Skt. Lauritz Kilde \#3 (Stenlille p.) was situated on fields belonging to the village of Saltofte.

7 In the south-Swedish regions of Småland and Östergötland, spring-cult celebrations took place on the Feast of the Ascension, in central and northern Sweden on the Eve of the Trinity, and in Norway both on St John's Eve, Trinity Eve and the Eve of St Olav (28 July) (Arwidsson 1965: 55; Bø 1965: 59). 
Something similar may be the case of Skt. Karens Kilde ('St Karen's Well', Højby p.), which according to post-medieval folklore owes it creation to a shipwreck of three sisters sailing out from Skåne. They all drowned, and the body of one of them, Karen, drifted ashore on the coast of Højby parish, where a holy well subsequently emerged due to her innocent purity (Svane 1984: 88-89). ${ }^{8}$ Whereas one may be sceptical about the historical value of this tale, which is not recorded in any medieval texts, the spring definitely appears to have been celebrated as a holy well in the Middle Ages already, even with the construction of an adjacent stone chapel as a local centre of pilgrimage. I could therefore be inclined to suggest that "St Karen" on the coast of Højby initially did not come from Skåne, but rather from Alexandria, as Skt. Karen was the common medieval Danish name for St Catherine of Alexandria. She held widespread popularity as saint in Denmark from the thirteenth century onwards, especially among the mendicant orders, who were represented in the region by Friars Minor (Franciscans) in Kalundborg and Friars Preachers (Dominicans) in Holbæk; the priory of the latter was even most probably dedicated to the very same Catherine.

A similar explanation is more difficult to provide for Skt. Gunnilds Kilde ('St Gunnild's Well', Hjembæk p.), said to owe its name to a local maiden, Gunhild, once again murdered on the site of the spring by robbers. No saint by the name of Gunhild or anything similar is otherwise known in Denmark. The name may derive from the adjacent hill name, Gundelsbjerg, which in itself is of uncertain etymological origin, from which an explanatory post-medieval folklore could have given birth to a Gunhild - but her promotion as actual saint is still somewhat surprising. Whatever the age and background is of the well, its healing power enjoyed extensive local celebration way into the late nineteenth century (Svane 1984: 85).

Beneath the before-mentioned "top ranks" of spring saints in Denmark, numerous other saints - both of international and regional veneration - were connected to holy wells spread around the Danish landscape. These include St Clement, who caused holy water with healing power to spring from the ground at three sites around Sjælland, for instance right by the parish church of Stillinge, causing both well and church to be dedicated to him. The local peasants were obliged to keep the well clear, or it was said that their cattle would die (Svane 1984: 97). St James had four springs around Denmark, one on a hill at Nostrup (Skt. Jakobs Kilde, Raklev p.), which appears to have been a cultic site since the Bronze Age (Svane 1984: 87). Also one of two Danish springs dedicated to St Paul was situated on Asnæs ('cape with ash trees', Asnæs p.), possibly with an adjacent "well chapel” attached to it (Svane 1984:

8 More fame was attributed to another of the sisters, Helene, whose body landed at Tisvilde (Frederiksborg c.) further east on the north coast of Sjælland, and it was from the famous well emerging there that wells of St Helen subsequently spread throughout the country. 
89). In all three cases there are indications of a cult going back beyond Christian times.

The most important holy well in north-western Sjælland apparently only took form in the late Middle Ages. On a site in the middle of the region, a few hundred metres south of Holmstrup parish church, was a spring that according to local folklore emerged when a tired monk by the name of Søren (the Danish form of Severin), on his way home from the Holy Land to Antvorskov Abbey fell asleep exhausted from thirst and fatigue; when he woke up, a refreshing spring had appeared by his side (Svane 1984: 87-88). This is, however, a classic example of how a post-medieval folklore tale has developed to offer a completely new explanation for a pre-Reformation spring saint cult. It is a well-established fact that the cult connected to Holmstrup Church and its adjacent spring was devoted to St Severin of Cologne. This German missionary bishop, who lived in the late fourth century, for some reason gained great saintly popularity in late medieval Denmark, and churches devoted to him in Gammel Ry (Skanderborg c.) and Holmstrup became national centres of pilgrimage (Jørgensen 1909: 37-38). Due to the huge income generated from pilgrims, the initially very modest and inferior parish church in Holmstrup was in the 1490s extended to almost six times its original size, to become one of the largest rural parish churches in the diocese of Roskilde (DK: 1789-1896). His cult was even so established that in this case the celebration was not centred around the Eve of John the Baptist, but on 23 October, the actual Feast of St Severin.

A final example of an apparent "spring saint" in north-western Sjælland concerns Skt. Kjelds Kilde (at Keldstrup, Stillinge p.). At first sight the saintly dedication may seem quite straightforward, since St Kjeld is a well-known Danish saint, who in his temporal life was a provost at the cathedral chapter of Viborg, before he died in 1150 and was papally recognized for "national beatification" in 1189. A problem with St Kjeld's Well in Stillinge parish is, however, that his cult is otherwise only known to have been a regional one, flourishing in the northern and central parts of Jylland. Another problem is that the connected folklore has no mention of St Kjeld, and even states that the spring emerged from rather impious circumstances, as it occurred when some local peasant tried to move a boundary pole at night (Svane 1984: 97). Since the spring is situated by the village of Keldstrup (quite certainly not named after St Kjeld), one might assume that the saintly devotion of the spring, just as suggested in the case of Skt. Gunnilds Kilde, is only to be seen as a post-medieval folklore creation based on the specific of a local place name, in this case Keldstrup.

\subsubsection{Other ecclesiastical terms in spring names}

In addition, a Christian-sacred connection to holy wells is also manifested by the use of other ecclesiastical terms as specifics in their names, such as Prcestekilde ('Priest Well', 5 in all of Denmark), Kapelkilde ('Chapel Well', 4), Kirkekilde ('Church Well', 1), Klosterkilde ('Monastery Well', 1), 
Biskopskilde ('Bishop's Well', 1), Provstekilde ('Provost Well', 1), Munkekilde ('Monk Well', 1), and Sortebrødrekilde ('Blackfriar Well', 1); they cover for a total of 2 per cent of the entire Danish material. No such examples are, however, found in north-western Sjælland. Within the region, finally, a handful of holy wells, to which healing power has been attributed, have names with no apparent religious content: Nykilde Brønd ('Newspring Well', Udby p.), Kilden ved Møllen ('Well by the Mill', Reerslev p.), Kilden ude pa Marken ('Well in the Field', Reerslev p.), and Ødemarks Kilde ('Wilderness Well', Bromme p.). This only goes to show that holiness of spring water was not dependent on religious elements occurring in the name of the well.

\section{Conclusion}

The majority of the 720 historically-known springs in Denmark have been accredited with healing power of supernatural origin, manifested in their names and/or local folklore tradition still supported by cultic rituals celebrated well into the nineteenth century. A frequently presented claim in folkloristic literature is that the bulk of these spring cults go back to pagan times before the introduction of Christianity (in Denmark around AD 1000), subsequently overtaken in medieval times by the Roman-Catholic Church. This only finds limited support in onomastic and archaeological evidence. A mere 2.5 per cent of Danish spring names explicitly appear to be of pagan origin, and as shown in the case study-example of Thorskilde ('Thor's Well'), some of these may even be much younger name constructions adapted to include local place-name elements with a "pagan sound" to them - even if that "sound" may be etymologically misleading. To this potentially "pagan group" of Danish spring names may be added a number of the neutrally-named instances Helligkilde ('Holywell'), covering 25 per cent of the entire material. From the name alone, these could equally well be pagan or Christian, but archaeological evidence in the case study-region of north-western Sjælland does suggest that some of them may have seen a cultic use since the Bronze Age; a similar high age is also indicated for some springs with clearly Christian names. On the whole, however, the saints of medieval Catholicism especially appear to have played a paramount role both in the naming (with saints in at least 30 per cent of Danish spring names) and in the cultic celebration of the wells. Often the medieval saintly cult attached to a well was changed beyond recognition in post-Catholic times, where Protestant folklore tradition offered completely new explanations for the origin and meaning of spring names, as the initial Catholic celebrations of the saints was increasingly forgotten. For this reason, Danish wells that may originally have been dedicated to the Holy Virgin, were later claimed to concern unfortunate maidens of local origin. But the distortion may also sometimes have gone the other way round, so that saintly devotion 
was invented for springs based on actual "un-saintly" place names in the vicinity. Thus, in total, holy wells offer an excellent example of how place names and landscape use, and human cognition of both, are closely interlinked and mutually influenced both ways. The naming of a landscape feature, like a well accredited with sacred power, is likely to reflect this cognition of its religious status, origin or cultic usage. But the table can also sometimes be turned, so that the cultic cognition of a site may be influenced or even derive from its name, when the original meaning of a name is forgotten and a new etymology is adapted to explain it. For name/place relations in the religious landscape, this is especially evident in periods when one religion overlapped with another as in Denmark from paganism to Christianity, and, perhaps even more so, from Roman Catholicism to Lutheran Protestantism.

\section{References}

Arwidsson, Greta. 1965. Källa [Spring]. Kulturhistorisk Leksikon for Nordisk Middelalder 10, 53-57.

Bø, Olav. 1965. Källa (Norge) [Spring (Norway)]. Kulturhistorisk Leksikon for Nordisk Middelalder 10, 57-59.

Danske Stednavne. Online database administered by the Name Research Section at the University of Copenhagen. (http://danmarksstednavne. navneforskning.ku.dk) (Accessed 2020-05-19.)

DK $=$ Jørgensen, Marie-Louise et al. (eds.). 1979-1996. Danmarks Kirker: Holboek Amt [Churches of Denmark: Holbæk County]. Copenhagen: Nationalmuseet.

Fellows-Jensen, Gillian \& Holmberg, Bente (eds.). 1992. Sakrale navne Rapport fra NORNAs sekstende symposium i Gilleleje 30.11-2.12.1990 [Sacred names - Report from the 16th NORNA symposium in Gilleleje 30.11-2.12.1990]. Uppsala: NORNA-förlaget.

Gammeltoft, Peder. 2009. Sakralitet i -torp-navne? Hvorfor tolkes navne som Frøstrup, Thorstrup og Tistrup, som de gør? [Sacrality in -thorp-names? Why are names like Frøstrup, Thorstrup and Tistrup interpreted in the way they are?] In Dam, Peder et al. (eds.), Torp - som ortnamn och bebyggelse [Torp - As place name and settlement], 31-42. Lund: Dialekt- och ortnamnsarkivet.

Jørgensen, Bent. 2008. Danske stednavne [Danish place names]. Copenhagen: Gyldendal.

Jørgensen, Ellen. 1909. Helgendyrkelse i Danmark [Cult of saints in Denmark]. Copenhagen: Hagerup.

Møller-Christensen, Vilhelm. 1939. Sct. Vilhelms Kapel - et Mirakelkursted og Helligvand ved AEbelholt Kloster $i$ det 13de til 16de Aarhundrede [The Chapel of St William - A miraculous spa and holy water at Æbelholt 
Abbey in the 13th to the 16th century]. Copenhagen: Ejnar Munksgaard. Schmidt, August F. 1926. Danmarks Helligkilder - Oversigt og Litteraturfortegnelse [Sacred springs of Denmark - Overview and bibliography]. Copenhagen: Det Schønbergske Forlag.

Sørensen, John Kousgård. 1968-1996. Danske sø- og ånavne [Danish names on lakes and streams], 8 vols. Copenhagen: C.A. Reitzels Forlag.

Svane, Siegfred. 1984. Danske Helligkilder og Loegedomskilder [Sacred springs and healing springs in Denmark]. Copenhagen: Finn Jacobsens Forlag. 